\title{
Determination of Total Aldehydes in Fuel Ethanol by MBTH Method - Sequential Injection Analysis
}

\author{
Fabio Santos de Oliveira ${ }^{a}$, Bárbara Cecília O. Leite ${ }^{b}$, Marta Valeria A. Santana de Andrade ${ }^{b}$ and \\ Mauro Korn ${ }^{*, b}$ \\ ${ }^{a}$ Instituto de Química, Universidade Federal da Bahia, Campus Universitário de Ondina, \\ 40170-290 Salvador - BA, Brazil \\ ${ }^{b}$ Departamento de Ciências Exatas e da Terra, Universidade do Estado da Bahia, Rua Silveira Martins, 2555, \\ 41195-001 Salvador - BA, Brazil
}

\begin{abstract}
Um sistema de análise por injeção sequencial (SIA) foi proposto para a determinação de aldeídos totais em amostras de álcool combustível. O procedimento foi baseado na reação dos aldeídos alifáticos com o 3-metil-2-benzotiazolona hidrazona (MBTH), levando à formação de um composto azul em presença de $\mathrm{Fe}^{3+}$. As estratégias de monossegmentação e amostragem binária foram empregadas para aumentar a sensibilidade do método. A taxa de reação entre o MBTH e aldeídos foi aumentada pelo aquecimento da zona da amostra, inserindo a bobina de reação na cavidade de um forno de microondas doméstico. A faixa linear de trabalho foi entre 0,3 e $6 \mathrm{mg} \mathrm{L}^{-1}$ e o desvio padrão relativo foi inferior a $2,5 \%$ em todas determinações. O limite de detecção calculado foi de $60 \mu \mathrm{g} \mathrm{L}^{-1}$. Os resultados do método proposto concordaram com os obtidos por 2,4-DNPH-CLAE. Nas condições otimizadas o procedimento proposto possibilitou a determinação de até 10 amostras por hora.
\end{abstract}

A sensitive SIA method was developed for total aldehyde determination in automotive fuel ethanol samples. It was based on the selective reaction of aliphatic aldehydes with 3-methyl-2benzothiazolone hydrazone (MBTH) with the formation of blue dye in the presence of $\mathrm{Fe}^{3+}$. Monosegmentation and binary sampling were employed to increase the sensitivity of the method. In order accelerate reaction rate of MBTH and aldehyde a mixing coil was inserted into a microwave oven cavity were the sample zone was homogeneously heated. The linear range was $0.3-6 \mathrm{mg} \mathrm{L}^{-1}$ with a precision, expressed as relative standard deviation, lower than $2.5 \%$ and detection limit of $60 \mu \mathrm{g} \mathrm{L}^{-1}$. The method has been successfully applied to the determination of total aldehydes in fuel ethanol and the results agreed with those obtained with 2,4-DNPH-HPLC. In the optimal condition the system can carry out 10 samples per hour.

Keywords: sequential injection analysis, total aldehyde determination, MBTH, binary sampling, monosegmentation

\section{Introduction}

The necessity to increase the use of renewable sources of energy is fundamental to make the world energy matrix more sustainable. In 1975, a pioneer brazilian alcohol program from sugar cane was implemented as a response to oil crisis. ${ }^{1-4}$ This brazilian automotive fuel program was basically intended to increase the production of alcohol for fuel purposes, in face of the threat from rising oil prices on the international market as well as a solution to the problem of the fluctuating sugar prices.

Other promising advantages related to the use of

* e-mail: mkorn@uneb.br ethanol as automotive fuel were associated to the decrease of the emissions of $\mathrm{CO}$ and total hydrocarbon in urban areas. ${ }^{5,6}$ Nevertheless, the use of ethanol as automotive fuel has lead to an increasing of concentration of carbonyl compounds in urban atmosphere. ${ }^{5-7}$ The aldehydes are of great importance to atmospheric chemistry due to the strong influence of these compounds have on photochemical reactions, which lead to the formation of important air pollutants, such as ozone, nitric acid and peroxyacilnitrates. ${ }^{5-7}$ The aldehydes, e.g., formaldehyde and acetaldehyde, have received a great deal of attention due to their mutagenic and carcinogenic nature, ${ }^{8}$ and their activity regarding sensory irritant (eyes and respiratory tract), nausea, headache, tiredness and thirst. ${ }^{8,9}$ 
Ethanol is susceptible to atmospheric oxidation to acetaldehyde. Hence, elevated amounts of the carbonyl compound can be found at unsuitable control of production stages, manipulation and storage. The presence of excessive amount of aldehydes in fuel can also affect the performance of spark ignition engine and lead to increase the local concentration of this pollutant. The environment on gas service must be considered unhealthful and gas service workers could be severely exposed for carbonyl compounds.

The legislation of Brazil do not imposes limits for aldehyde content in fuel ethanol, ${ }^{10}$ even though the limits for alcohol to use in the alco-chemicals industry are 75 and $65 \mathrm{mg} \mathrm{kg}^{-1}$ for acetaldehyde and formaldehyde, respectively. ${ }^{11}$

Several methods were developed for aldehyde determination, these includes color reaction with chromotropic acid, ${ }^{12,13}$ pararosaniline - bisulfite (Schiff reagent) ${ }^{14,15}$ malachite green- bisulfite, ${ }^{16,17}$ brilliant greenbisulfite, ${ }^{18}$ enzymatic methods, ${ }^{19-21}$ liquid chromatography by derivatization with 2,4-dinitrophenylhydrazine ${ }^{22-30}$ and reaction with 3-methyl-2-benzothiazolone hydrazone (MBTH). ${ }^{31-38}$

Chromotropic acid reacts with fomaldehyde forming a violet compound that can be detected by spectrophotometry at $570 \mathrm{~nm} \cdot{ }^{12,13}$ However, this reaction employs concentrated sulphuric acid $(>85 \%)$ making tough its application with automatic flow systems for aldehyde determination in fuel ethanol samples, while methods based on the reaction with p-rosaniline, malachite green or brilliant green associated with $\mathrm{HSO}_{3}{ }^{-}$suffer for interference for low levels of ethanol. ${ }^{14-18}$

High performance liquid chromatography employing 2,4-dinitrophenilhydrazine (2,4-DNPH) as chromogenic reagent and spectrophotometric detection at $365 \mathrm{~nm}$ is the standard method for carbonyl compounds determination in atmospheric air samples, offering excellent sensibility and selectivity. ${ }^{22-30}$ Nonetheless, the development of automatic flow systems with spectrophotometric detection for aldehydes determination using 2,4-dinitrophenilhydrazine without chromatographic separation step is considered as not feasible, since the reagent and products with aldehydes present absorption maxima at the same wavelength range. The consumption of toxic organic solvents on mobile phase and time interval for aldehydes determination can be classified as additional drawbacks for chromatographic method.

The MBTH method was employed to total aliphatic aldehydes determination in several samples. ${ }^{31-37}$ This method do not suffer interference from ethanol even thought compounds not usually presents in fuel, such as aromatic amines, Schiff bases, carbazoles and phenols at high concentration levels interfere in aldehyde determination. Then, MBTH is a suitable chromogenic reagent for total aliphatic aldehyde determination in fuel ethanol samples.

Automation of analytical methods by flow system is a worthy strategy for routine analysis due to increase analytical throughput, diminishing operator handling and exposition to toxic chemicals. In Brazil some laboratories are dedicated to the quality control of the fuels commercialized and requisition for fuel control analysis has increased. Sequential injection analysis (SIA) can be considered as a profitable automation strategy ${ }^{39,40}$ for the determination of several fuel parameters due to a sample aliquot can be split and send to different detectors positioned in specific valve channels. In particular, the organic nature of the samples cannot result in degradation of the pumping tubes since SIA relies on aspiration of the sample into a holding coil and the sample never reaches the pumping tubes. Sequential injection system provides high flexibility and robustness required for routine analysis of fuel quality control. For those reasons, in this work a system based on binary and monosegmented sampling for the determination of total aliphatic aldehydes in automotive ethanol samples with 3-methyl-2benzothiazolone hydrazone and $\mathrm{Fe}^{3+}$ as oxidizing agent by employing one multiposition valve was exploited.

\section{Experimental}

\section{Reagents and solutions}

A solution of 3-methyl-2-benzothiazolone hydrazone (Merck, Darmstadt, Germany) $0.4 \%(\mathrm{~m} / \mathrm{v})$ was prepared dissolving $400 \mathrm{mg}$ of the reagent in $100 \mathrm{~mL}$ of $0.1 \mathrm{~mol} \mathrm{~L}^{-1}$ $\mathrm{HCl}$, stocking in amber flask at $5{ }^{\circ} \mathrm{C}$ for a week at the most. $1 \mathrm{~g}$ of $\mathrm{FeCl}_{3} \cdot 6 \mathrm{H}_{2} \mathrm{O}$ (Merck, Darmstadt, Germany) was used dissolving in $100 \mathrm{~mL}$ of $0.1 \mathrm{~mol} \mathrm{~L}^{-1} \mathrm{HCl}$ solution.

Acetaldehyde stock solution $\left(1 \mathrm{~g} \mathrm{~L}^{-1}\right)$ was prepared by dissolving $0.1 \mathrm{~g}$ of $99 \%$ acetaldehyde (Merck, Germany) in $100 \mathrm{~mL}$ of water. References acetaldehyde solutions from 0.3 to $6 \mathrm{mg} \mathrm{L}^{-1}$ were prepared from stock solution by dilution with deionized water. $200 \mu \mathrm{L}$ of ethanol sample solutions were adequately diluted to $10 \mathrm{~mL}$ with water and used without any other preliminary treatment.

\section{Apparatus}

A multiposition valve (VCI, Valco Instruments) was employed to select and direct solutions. A spectrophotometer Femto 432 (S. Paulo, Brazil) equipped with borosilicate flow cell with $10 \mathrm{~mm}$ optical path and $200 \mu \mathrm{L}$ cell volume. A peristaltic pump Gilson Minipuls 3 (Villiers- 
Le-Bell, France) was employed for fluid propulsion. Isoversinic and Teflon tubes ( $0.8 \mathrm{~mm}$ i.d.) were used in flow system. A microcomputer Pentium I equipped with PCL 711S (Advantech, Taipei, Taiwan) was employed to control multiposition valve, peristaltic pump and signal acquisition. A domestic microwave oven LG MS-74ML (Manaus, Brazil) was employed to heat up solutions in a heating coil and accelerate the reaction without any further instrumental modification. Once the microwave oven was not modified for this application, special safety during operation was not necessary.

Chromatographic determination was performed with a high performance liquid chromatography CG-480C (CG Instrumentos Cientificos, S. Paulo, Brazil) equipped with a Rheodyne injector and a variable UV detector set at $360 \mathrm{~nm}$. The analytical column used was LiChrospher C18 $5 \mu \mathrm{m}, 250 \mathrm{~mm} \times 4 \mathrm{~mm}$ i.d. (Merck, Germany). The mobile phase was methanol : water : acetonitrile (75.0:24.5:0.5 $\mathrm{v} / \mathrm{v} / \mathrm{v})$ at $1.0 \mathrm{~mL} \mathrm{~min}^{-1}$ and sampling loop of $20 \mu \mathrm{L}$ was used throughout. ${ }^{29}$

\section{Sequential Injection System and procedure}

A schematic diagram of the flow manifold is shown in the Figure 1. Table 1 illustrates the steps for aldehyde determination in fuel sample. Aliquots of $82 \mu \mathrm{L}$ of previously diluted alcoholic fuel sample and MBTH solution were sequentially loaded in the sampling coil. After mixing, the sample zone was directed to the microwave oven channel where it was heated during $20 \mathrm{~s}$ at the lower power $(277 \mathrm{~W})$. After this period, the sample zone was cooled at $25^{\circ} \mathrm{C}$ in the same channel, and aspired to sampling coil where $82 \mu \mathrm{L}$ of $\mathrm{Fe}^{3+}$ solution was added

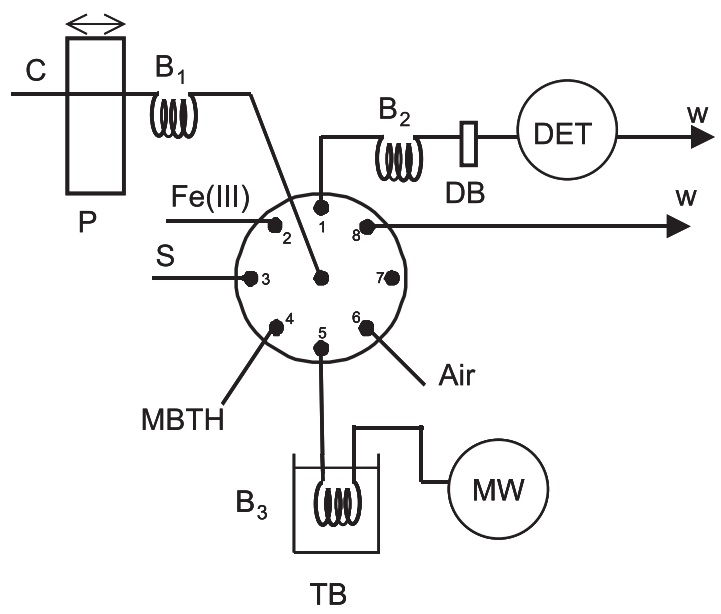

Figure 1. Diagram of sequential injection manifold. $\mathrm{C}=$ carrier $\left(\mathrm{H}_{2} \mathrm{O}\right), \mathrm{P}=$ peristaltic pump, $\mathrm{S}=$ sample, $\mathrm{TB}=$ cooling bath at $25^{\circ} \mathrm{C}$, $\mathrm{MW}=$ microwave oven at $277 \mathrm{~W}, \mathrm{DB}=$ bubble remover, $\mathrm{DET}=$ spectrophotometer $(\lambda=630 \mathrm{~nm}), \mathrm{W}=$ waste, $\mathrm{B}_{1}, \mathrm{~B}_{2}$ e $\mathrm{B}_{3}=$ holding $(5 \mathrm{~m})$, reaction $(1 \mathrm{~m})$ and cooling $(1.2 \mathrm{~m})$ coils, respectively.
Table 1. Steps for aldehyde determination on the sequential injection system

\begin{tabular}{lccc}
\hline Step & $\begin{array}{c}\text { Valve } \\
\text { position }\end{array}$ & $\begin{array}{c}\text { Flow rate/ } \\
\mathrm{mL} \mathrm{min}^{-1}\end{array}$ & time/s \\
\hline Sample and MBTH insection & 6 & -1 & 3.0 \\
& 3 & -1 & 0.2 \\
& 4 & -1 & 0.2 \\
& 3 & -1 & 0.2 \\
& 4 & -1 & 0.2 \\
Sending to microwave oven & $\mathrm{b} \ldots$ & $\ldots$ & $\ldots$ \\
& 6 & -1 & 3.0 \\
Cooling of sample zone & 5 & 1 & 76.0 \\
Fe(III) addition & 5 & 0 & 20.0 \\
& 5 & -1 & 70.0 \\
& 5 & -1 & 0.4 \\
& 2 & -1 & 0.2 \\
Sending to analytical path & 5 & -1 & 0.4 \\
and stop flow & 1 & -1 & 0.2 \\
To detector / acquisition & 1 & 2 & 32 \\
data process & 1 & 0 & 90 \\
\end{tabular}

a Positive flow rates indicate pumping and negative aspiration;

${ }^{\mathrm{b}}$ These steps were repeated for more 22 times; ${ }^{\mathrm{C}}$ At this stage the microwave oven was turned on at $277 \mathrm{~W}$.

to the monosegment. Finally, the mixture was send to the detector channel, the air bubbles were removed (DB) and the signal was acquired at $630 \mathrm{~nm}$ only in this stage. A cleaning cycle before sample changes was accomplished by the aspiration of new sample solution and the solution excess were directed to waste channel without start the signal acquisition process.

In order to compare the results obtained by the proposed method, an HPLC procedure based on aldehydes derivatization with 2,4-DNPH was chosen as reference procedure. Samples aliquots of $50 \mathrm{~mL}$ were transferred to 10 $\mathrm{mL}$ volumetric flasks and the volume adjusted with aqueous-organic acidic solution $0.05 \%$ 2,4-DNPH in $1 \%$ (v/v) $\mathrm{H}_{3} \mathrm{PO}_{4}$ was injected directly into the HPLC system.

\section{Results and Discussion}

The selective reaction between MBTH and aliphatic aldehydes (C1-C3) leads to produce the corresponding aldazine. Subsequently, it is converted to a blue tetrazopentamethincyanine dye under oxidative coupling with a second MBTH molecule in the presence of Fe(III), ${ }^{31-37}$ as illustrated in Scheme 1. The original method for formaldehyde determination recommended a delay time of $1 \mathrm{~h}$ for complete aldazine production and more $12 \mathrm{~min}$ after $\mathrm{Fe}^{3+}$ addition for the blue color formation. ${ }^{31}$ As acetaldehyde is the principal carbonyl compound in ethanol fuel samples, kinetics of MBTH-acetaldehyde 
<smiles>[R]C=NN=c1sc2ccccc2n1C</smiles><smiles></smiles>

Scheme 1.

reaction in batch were evaluated and it was concluded that 25 and 12 min were sufficient for aldazine and blue dye formation, respectively.

In order to increase the analytical throughput a sequential injection strategy was developed. To minimize the loss of sensitivity the sample zone was monosegmented by air bubbles to reduce the sample dispersion. ${ }^{41}$ In addition, to attain the best mixture condition, binary sampling strategy was selected for the insertion of MBTH and $\mathrm{Fe}^{3+}$ solutions in the analytical path.

To overcome the high time interval required for aldehyde determination using the proposed flow system, a coil was inserted in a microwave oven for heating MBTH - sample segment and to accelerate aldazine formation. The effect of heating time on absorbance was evaluated (Figure 2). A heating time of $20 \mathrm{~s}$ was selected, since for interval times lower than $20 \mathrm{~s}$ the sensibility of the proposed analytical procedure was strongly harmed and higher heating times leaded to air bubbles fragmentation with worst repeatability. Afterward, the sample zone was cooled in water bath $\left(25^{\circ} \mathrm{C}\right)$, because oxidative coupling with $\mathrm{Fe}^{3+}$ addition and the blue color yield do not occur suitably in heated medium, leading to yellow-pale green color formation and higher blank signal. ${ }^{31}$ The length of cooling coil was also evaluated to minimize traveling time and to maximize the net absorbance (Figure 3). It was observed that by increasing the cooling coil the analytical signal also increased. Thus, a cooling coil of $120 \mathrm{~cm}$ was selected since it attained the compromise between sample throughput and efficient cooling for blue dye yield. The sensibility increasing with the length of cooling coil can also be related with the increase of traveling time leading to more complete aldazine formation, since the selected heating time did not lead to complete MBTH/ aldehyde reaction.

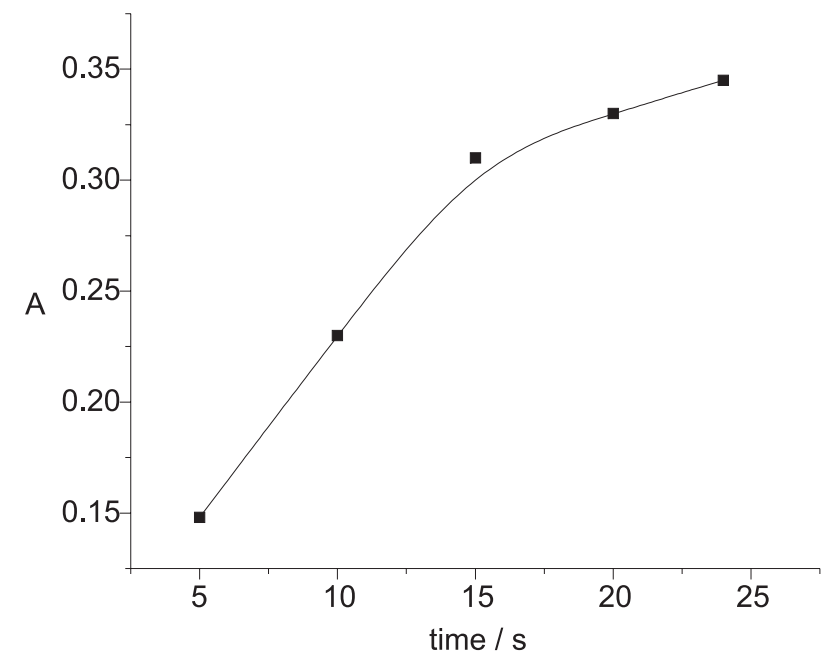

Figure 2. Effect of microwave heating time at $277 \mathrm{~W}$ on analytical signal for $3.0 \mathrm{mg} \mathrm{L}^{-1}$ acetaldehyde solution.

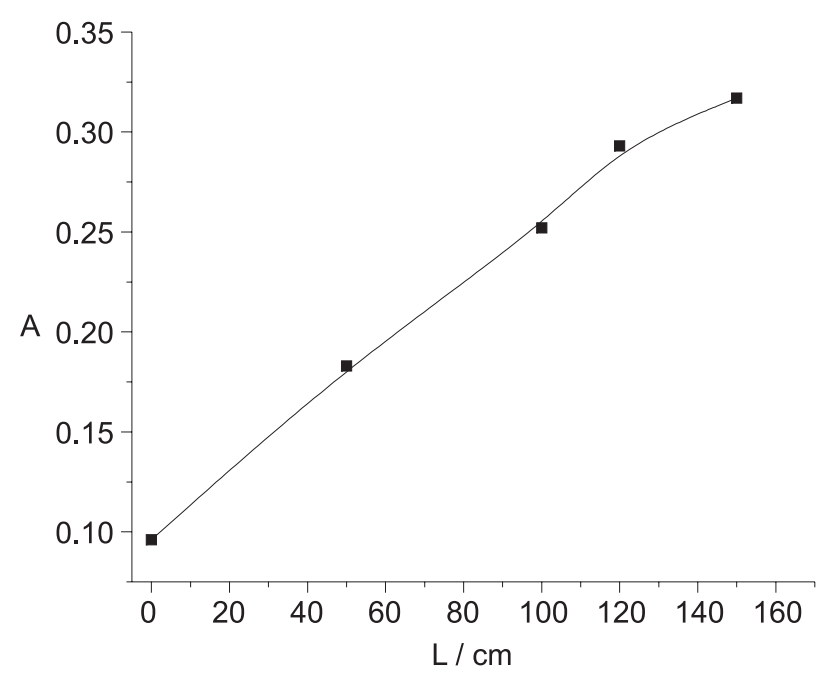

Figure 3. Effect of cooling coil $\left(\mathrm{B}_{3}\right)$ length on analytical signal for a $3.0 \mathrm{mg} \mathrm{L}^{-1}$ acetaldehyde solution.

The total sample volume injected by binary sampling was evaluated (Figure 4) since generally this parameter is a powerful tool to change the sensibility in flow systems. This study was performed maintaining the volume of each sample, MBTH and $\mathrm{Fe}^{3+}$ solutions aliquots constant at $3.46 \mu \mathrm{L}$, but varying the number of aliquots of each solution sampled. It was observed the increase of analytical signal by increasing the aliquots number. For the aldehyde concentration level expected in alcoholic fuel the sampling of 24 aliquots was considered adequate in order to maintain the same proportion of sample and reagents. In this condition $c a .82 \mu \mathrm{L}$ of sample, $\mathrm{MBTH}$ and $\mathrm{Fe}^{3+}$ solutions were employed on further experiments.

The effect of the length of the reaction coil on the sensitivity employed after $\mathrm{Fe}^{3+}$ insertion to react with produced aldazine is illustrated in Figure 5. After studies a reaction coil of $100 \mathrm{~cm}$ was selected, since for larger mixing 


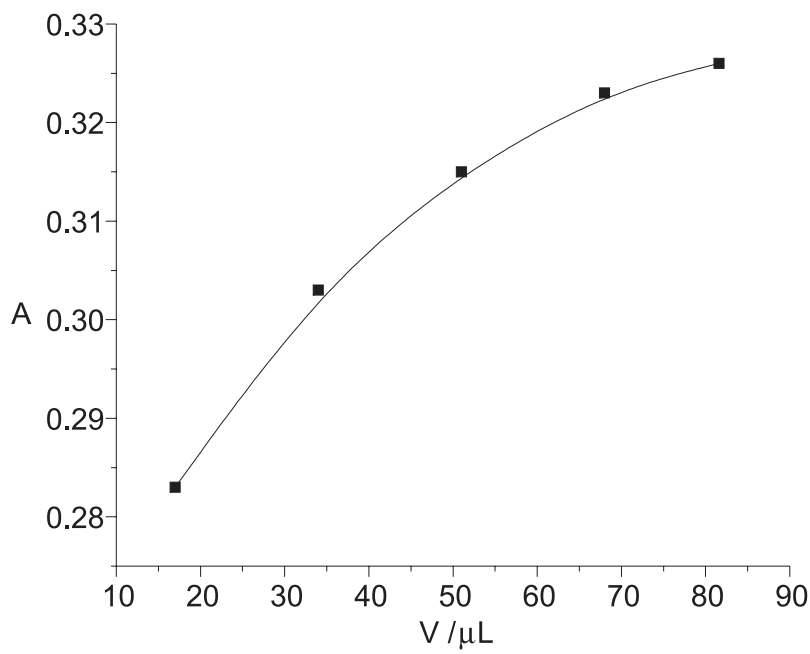

Figure 4. Effect of sample volume on analytical signal for a $3.0 \mathrm{mg}$ $\mathrm{L}^{-1}$ acetaldehyde solution.

coils a significant peak height increasing was not observed.

At the optimized conditions a linear relationship between peak height and acetaldehyde concentration in the range from 0.3 and $6 \mathrm{mg} \mathrm{L}^{-1}$ was attained $(\mathrm{A}=0.08758 \mathrm{C}$ $\left.\left(\mathrm{mg} \mathrm{L}^{-1}\right)+0.06635, \mathrm{R}=0.9996\right)$. The proposed system showed high repeatability with relative standard deviation lower than $2.5 \%$ for all measures (Figure 6). In this condition the system carried out about 10 samples per hour. The detection limit ( $3 \sigma$ ) was estimated as $0.06 \mathrm{mg} \mathrm{L}^{-1}$.

The sequential injection system was employed for determination of total aldehydes in fuel ethanol samples, expressed as acetaldehyde, and the results were compared with those obtained with liquid chromatography 2,4-dinitrophenilhydrazine method and the results agreed at $95 \%$ of confidence (Table 2) when a correction factor of 0.882 was employed. This factor adjusts different molar absorption coefficients of aldehydes found in ethanol

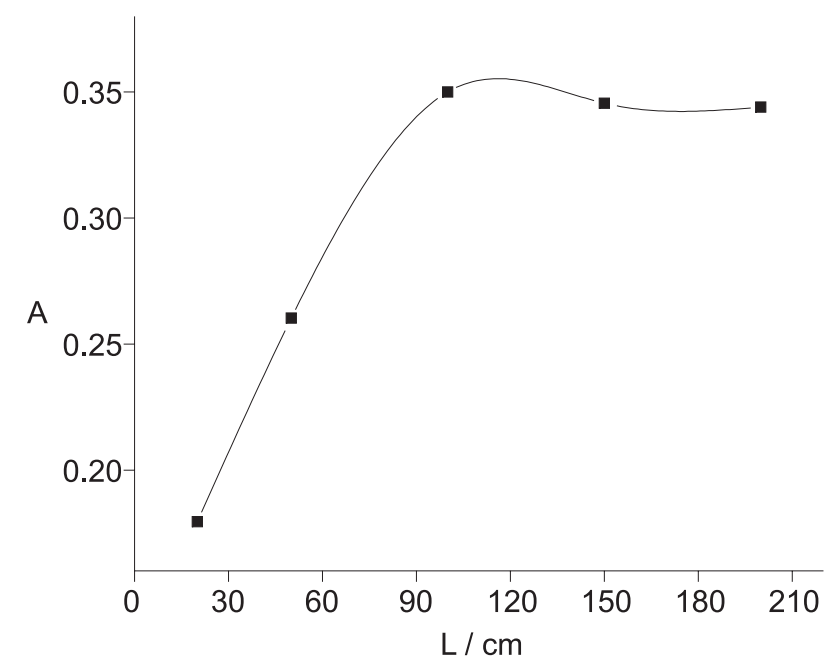

Figure 5. Effect of reaction coil $\left(\mathrm{B}_{2}\right)$ length on analytical signal for a $3.0 \mathrm{mg} \mathrm{L}^{-1}$ acetaldehyde solution.

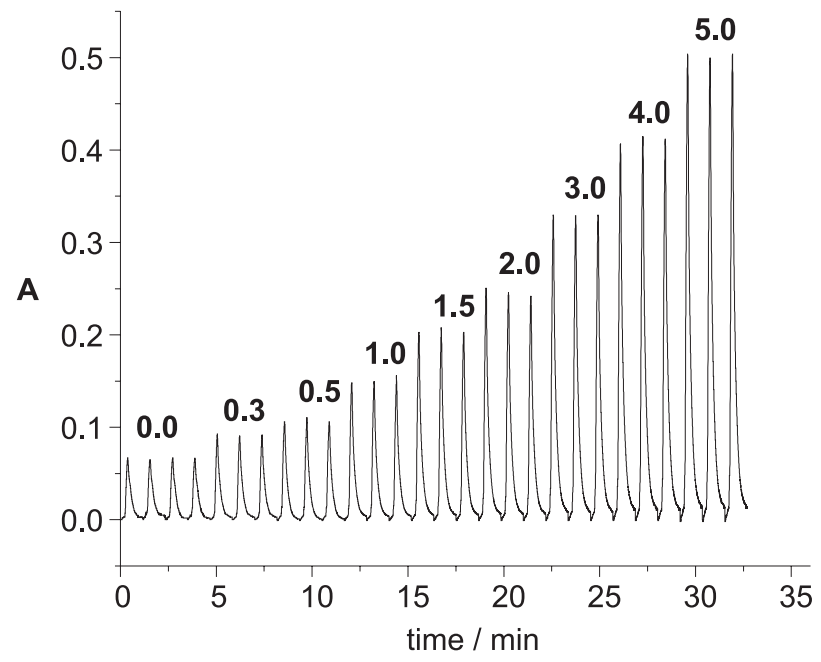

Figure 6. Recording of acetaldehyde calibration curve with concentrations expressed in $\mathrm{mg} \mathrm{L}^{-1}$ obtained during acquisition data process.

samples leading correct expression of total aldehydes as acetaldehyde. ${ }^{32}$ This correction factor was in agreement with the theoretical one obtained using of molar absorptivity of aldehydes $(0.96) .^{31}$

Total aldehyde values obtained in analyzed samples range from 90 to $1290 \mathrm{mg} \mathrm{L}^{-1}$ of acetaldehyde. A further dilution was performed for the last three samples on Table 2 in order to adjust to the experimental range due to their abnormal aldehyde contents. Samples with unusually high amounts of aldehydes also presented low $\mathrm{pH}$ levels or high electrical conductivity. This result had indicated that high aldehyde contents could be related with the addition of mineral acids at the fermentation stage to accelerate alcohol production. Addition of mineral acids at fermentation stage is an usual practice to adequate $\mathrm{pH}$ to levedures activity, suppressing other microorganism action. On the other hand, excessive addition of acids can

Table 2. Comparison between results obtained by the proposed SIA method and HPLC for fuel ethanol samples $(\mathrm{n}=3)$ and parameters specified by legislation

\begin{tabular}{ccccc}
\hline \multicolumn{2}{c}{$\begin{array}{c}\text { Total aldehydes/mg L} \\
\text { of acetaldehyde }\end{array}$} & & \multicolumn{2}{c}{ Specified parameter } \\
\cline { 5 - 5 } \cline { 4 - 5 } SIA & HPLC & & $\mathrm{pH}^{\mathrm{a}}$ & $\begin{array}{c}\text { Conductivity } \\
\mu \mathrm{S} \mathrm{m}^{-1}\end{array}$ \\
\hline $90 \pm 5$ & $91 \pm 3$ & & 6.4 & 101 \\
$221 \pm 6$ & $222 \pm 2$ & & 6.9 & 110 \\
$140 \pm 2$ & $138,9 \pm 0,5$ & & 6.9 & 152 \\
$132 \pm 4$ & $130 \pm 2$ & & 5.9 & 183 \\
$176 \pm 1$ & $179 \pm 1$ & & 7.2 & 187 \\
$155 \pm 9$ & $165 \pm 7$ & & 6.9 & 200 \\
$309 \pm 12$ & $292 \pm 8$ & & 5.5 & 163 \\
$415 \pm 17$ & $421 \pm 8$ & & 6.2 & 215 \\
$1290 \pm 21$ & $1289 \pm 22$ & 6.0 & 478 \\
\hline
\end{tabular}

${ }^{\mathrm{a}}$ The $\mathrm{pH}$ must be in the range of 6.0-8.0; ${ }^{\mathrm{b}}$ Maximal acceptable conductivity $500 \mu \mathrm{S} \mathrm{m}^{-1}$ 
lead to the alcohol oxidation, producing aldehydes and carboxilic acid.

These extremely high amounts of aldehydes in comparison with limits imposed for ethanol in alcochemicals industry can be unhealthful for automotive fuel workers and affect engine performance. Notwithstanding the legislation for countries that use ethanol as automotive fuel could establish limits for aldehydes, in order to specify the minimum quality control.

\section{Conclusions}

The proposed system was successfully applied for total aldehyde determination in fuel ethanol samples with good repeatability and accuracy. Monosegmented and binary sampling in sequential injection analysis has presented high sensibility, low detection limit and large linear range. This system was suitable to routine analysis as it shown high sample throughput sample, low reagents consumption and waste generation with good ruggedness and automation degree. The level of aldehydes in automotive ethanol could be used as a quality control parameter since this information can be related to unsuitable condition of production, transport and storage of fuel.

\section{References}

1. Moreira, J. R.; Goldemberg, J.; Energ. Policy 1999, 27, 229.

2. Saint, W. S.; World Dev. 1982, 10, 223.

3. Dincer, I.; Renew. Sustain. Energ. Rev. 2000, 4, 157.

4. de Oliveira, J. A. P.; Renew. Sust. Energ. Rev. 2002, 6, 129.

5. de Andrade, J. B.; Andrade, M.V.A.S.; Pinheiro, H.L.C.; J. Braz. Chem. Soc. 1998, 9, 219.

6. Miguel, A.H.; de Andrade, J. B.; J. Braz. Chem. Soc. 1990, 3, 124.

7. Andrade, M.V.A.S.; Pinheiro, H.L.C.; Pereira, P.A.P.; de Andrade, J. B.; Quim. Nova 2002, 25, 1117.

8. Formaldehyde and Other Aldeydes, National Research Council, Committee on Aldehydes; National Academy of Science Press, Washington, DC, 1981.

9. Goldscimidt, B.M.; J. Environ. Sci. Health 1984, 2, 231.

10. Agência Nacional do Petróleo, Portaria No 126, de 8 de agosto de 2002 Estabelece as especificações para comercialização do Álcool Etílico Anidro Combustível (AEAC) e do Álcool Etílico Hidratado Combustível (AEHC) em todo o território nacional e define obrigações dos agentes econômicos sobre o controle de qualidade do produto.

11. Norma Brasileira, NBR 10892 Janeiro de 1990.

12. Fagnani, E.; Melios, C.B.; Pezza, L.; Pezza, H.R.; Talanta 2003, 60, 171.
13. Pretto, A.; Milani, M.R.; Cardoso, A.A.; J. Environ. Monit. 2000, 2, 566.

14. Bosque-Sendra, J.M.; · Pescarolo, S.; Cuadros-Rodríguez, L.; - García-Campaña, A.M.; Almansa-López, E.M.; Fresenius J. Anal. Chem. 2001, 369, 715.

15. Kok, G. L.; Gitlin, S. N.; Gandrud, B. W.; Lazrus. A. L.; Anal. Chem. 1984, 56, 1993.

16. Afkhami, A.; Rezaei, M.; Microchem. J. 1999, 63, 243.

17. Afkhami, A.; Parham, H.; Rezaei, M.; Anal. Lett. 2000, 33, 527.

18. Safavi, A.; Ensafi, A. A.; Anal. Chim. Acta 1991, 252, 167.

19. Lazaro, F.; de Castro, M. D. L.; Valcarcel, M.; Anal. Chim. Acta 1986, 185, 57.

20. Almuaibed, A. M.; Townshend, A.; Anal. Chim. Acta 1987, 198, 37.

21. Papaefstathiou, I.; Bilitewski, U.; de Castro, M. D. L.; Anal. Chim. Acta 1996, 330, 265.

22. Possanzini, M.; Di Palo, V.; Cecinato, A.; Atmos. Environ. 2003, 37, 1309.

23. Ho, S. S. H.; Yu, J. Z.; Environ. Sci. Technol. 2004, 38, 862.

24. Schulte, E.; Anal. Bioanal. Chem. 2002, 372, 644.

25. Vogel, M.; Büldt, A.; Karst, U.; Fresenius J. Anal. Chem. 2000, 366, 781.

26. Selim, S.; J. Chromatogr. 1977, 136, 271.

27. Kuwata, K.; Uebori, M.; Yanasaki, Y.; J. Chromatogr. Sci. 1979, 17, 264.

28. de Andrade, J. B.; Miguel, A. H.; Quim. Nova 1985, 356, 1985.

29. de Andrade, J. B.; Andrade, M. V.; Pinheiro, H. L. C.; Martins, R. A.; Borges, E. L.; Am. Lab. 1999, 31, 22.

30. Oliveira, A. E.; de Andrade, J. B.; Quim. Nova 1994, 17, 13.

31. Sawicki, E.; Stanley, T.W.; Hauser, T.R.; Elbert, W.; Noe, J.L.; Anal. Chem. 1961, 33, 722.

32. Altshuller, A. P.; Leng, L. J.; Anal. Chem. 1963, 35, 1541.

33. Hauser, T.R.; Cummins, R. L.; Anal. Chem. 1964, 36, 679.

34. Barary, M. H.; El-Yazbi, F. A.; Bedair, M. A.; Anal. Lett. 1991, $24,857$.

35. Goebel, R.; Krug, A.; Kelllner, R.; Fresenius J. Anal. Chem. 1993, 347, 491.

36. Zurek, G.; Karst, U.; Anal. Chim. Acta 1997, 351, 247.

37. Pereira, E. A.; Cardoso, A.A.; Quim. Nova 2001, 24, 443.

38. Chan, W. H.; Shuang, S.; Choi, M.M.F.; Analyst 2001, 126, 720.

39. Ruzicka, J.; Anal. Chim. Acta 1992, 261, 3.

40. Lenehan, C. E.; Barnett, N. W.;Lewis, S. W.; Analyst 2002, 127, 997.

41. Pasquini, C.; Oliveira, W. A.; Anal. Chem. 1985, 57, 2575.

Received: April 14, 2004

Published on the web: December 16, 2004 